\title{
Survival of occlusal ART restorations in primary molars placed in school environment and hospital dental setup-one year follow-up study
}

\author{
Noor-Mohammed Roshan ${ }^{1}$, Basha Sakeenabi ${ }^{2}$ \\ ${ }^{1}$ M.D.S. Assistant Professor, Department of Pedodontics and preventive dentistry, College of dental sciences, Davangere, Kar- \\ nataka, India, 577004 \\ ${ }^{2}$ M.D.S. Reader, Department of Community Dentistry, College of dental sciences, Davangere, Karnataka, India, 577004
}

Correspondence:

Department of Pedodontics and Preventive Dentistry, College of Dental Sciences,

Davangere, Karnataka, India, 577004.

drroshannm@yahoo.co.in

Received: 24/09/2010

Accepted: $26 / 12 / 2010$

\begin{abstract}
Roshan NM, Sakeenabi B. Survival of occlusal ART restorations in primary molars placed in school environment and hospital dental setupone year follow-up study. Med Oral Patol Oral Cir Bucal. 2011 Nov 1;16 (7):e973-7.

http://www.medicinaoral.com/medoralfree01/v16i7/medoralv16i7p973.pdf
\end{abstract}

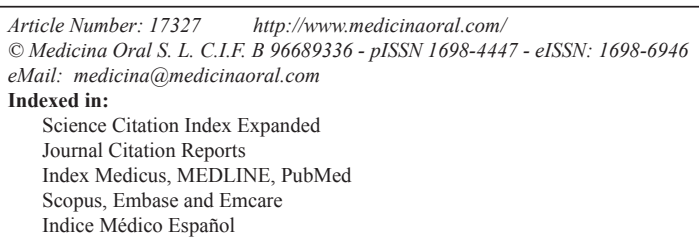

Indice Médico Español

\begin{abstract}
Objective: The objectives of this clinical study were to: evaluate the survival of occlusal atraumatic restorative treatment (ART) restorations, on a longitudinal basis, in the primary molars of children; and compare the success rate of ART restorations placed in school environment and in hospital dental setup.

Study design: One dentist placed 120 ART restorations in 60 five- to seven year-olds who had bilateral matched pairs of carious primary molars. A split-mouth design was used to place restorations in school and in hospital dental setup, which were assigned randomly to contralateral sides. Restorations were evaluated after 6 and 12 months using the ART criteria.

Results: The survival rate of ART restorations placed in school environment was $82.2 \%$ at the 6-month assessment and $77.77 \%$ at the 12 -month assessment. The success rates of ART restorations placed in hospital dental setup in the 2 assessments were $87.7 \%$ and $81.48 \%$, respectively. There was no statistically significant difference between the ART restorations placed in school environment and hospital dental setup in both assessments $(\mathrm{P}>0.05)$. The main cause of failure was the loss of restoration.

Conclusions: The one year success rate of occlusal ART restorations in primary molars was moderately successful. The ART technique's done in hospital dental setup was not proven to be better than restorations placed in school environment.
\end{abstract}

Key words: Atraumatic restorative treatment, dental caries, primary molars. 


\section{Introduction}

Atraumatic restorative treatment (ART) is a minimally invasive technique for removing soft, demineralized, carious dental tissue using hand instruments, followed by restoration of the tooth with an adhesive restorative material-routinely glass ionomer cement (GIC) (1). ART was originally developed for and introduced to economically underdeveloped populations with limited resources $(1,2)$. It also has applications in industrial countries, however, especially for: very young children who are being introduced to oral care (3), patients who experience extreme fear or anxiety about dental procedures $(4,5)$, mentally and/or physically handicapped patients (5), home-bound elderly and nursing home resident patients (6),and patients from high-risk caries clinics who can benefit from ART as an intermediate treatment to stabilize conditions $(3,7)$.

Although ART uses only manual excavation and restoration of cavity with chemically adhesive restorative material, the environment in which it is performed may influence the efficacy of the restoration. The ART procedure is established for field and detailed procedural instructions have been laid in manual for ART by WHO. With the increase in knowledge of caries process and improvement in adhesive dental restorative materials the procedure of ART is implemented as minimal invasive technique in hospital dental setup also (8). Patient and operator positioning, illumination, operator comfort and accessibility for excavation of decay are the few factors that influence the efficacy of ART restoration. No previous study has directly compared the success of ART restorations in situations where it is performed in school environment and in hospital dental setup.

The objectives of this clinical study were to:

1. Evaluate, on a longitudinal basis, the effectiveness of occlusal Class I ART restorations placed in primary molars of children over a period of one year.

2. Compare the efficacy of class I ART restorations by comparing the longevity of restorations performed in school environment and in hospital dental setup.

\section{Material and Methods}

Sixty primary school children who had a matched pair of primary molars with an occlusal carious lesion of a similar size extending into the dentine with an entrance large enough to allow access by hand instruments-were selected for ART treatment. Teeth were excluded if there was a definite or likely pulpal exposure or an associated abscess. Prior to treatment, written consent was obtained from all parents/guardians through the school authorities.

120 restorations were placed in 60 children by the same dentist with the help of one dental hygienist using the ART technique. A split-mouth design was used to place the ART restorations in school environment and hospital dental setup, assigned randomly to contralateral sides. The treatment was performed in the schools following the standard ART procedure using hand instruments and a portable light. Same children were treated for another ART restoration in department of pedodontics clinic on dental chair. The restoration material used was Fuji IX Glass Ionomer Cement (GC Fuji IX, Tokyo, Japan), a hand-mixed glass ionomer recommended for use in Class I primary teeth. Each child received 2 ART restorations: one performed in school environment; and one performed in pedodontic clinic dental setup.

The press-finger technique was used to condense the material into the cavity and adjacent pits and fissures, thus providing a sealant restoration by using a gloved finger lightly lubricated with petroleum jelly. After the restorations were set initially and the dentist performed an occlusal adjustment, cavity varnish was applied over them. No local anesthesia was used for any of the restorations. Code and criteria for the assessment of ART restorations after 6 months and 12 months is summarized in table 1 .

One blinded experienced dentist who was not involved in the placement of restorations evaluated the ART restorations after 6 and 12 months using sharp sickle shaped explorers, WHO CPI periodontal probes, plane mirrors, and a portable light source. The ball end of the CPI probe $(0.5-\mathrm{mm}$ in diameter) was used to measure the size of any marginal defect and the amount of wear. The restorations that scored codes 0,1 , and 2 were considered successful; codes 3 to 6 were considered failures; and codes 7 and 8 were excluded from the analysis. Duplicate examinationswere conducted on a random $15 \%$ sample of children in each follow-up examination to assess the inter examiner reproducibility; the overall Cohen's kappa value in both assessments was 0.83 .

The data were analyzed using a software program (SPSS 10.0 for Windows). McNemar's test was used to assess the statistically significant survival rates in the 2 ART techniques in school and in hospital dental setup. The difference was statistically significant if $\mathrm{P}<0.05$.

Table 1. Code and Criteria Used For the Assessment of ART Restorations.

\begin{tabular}{|l|l|}
\hline Code & Criteria \\
\hline 0 & Present, and in good condition \\
\hline 1 & Present, with slight marginal defect; no repair is needed \\
\hline 2 & Present, with slight wear; no repair is needed \\
\hline 3 & Present, with marginal defect $>0.5 \mathrm{~mm}$; repair is needed \\
\hline 4 & Present, with wear $>0.5 \mathrm{~mm}$; repair is needed \\
\hline 5 & Not present, restoration partly or completely missing \\
\hline 6 & Not present, restoration replaced by another restoration \\
\hline 7 & Tooth is missing, exfoliated, or extracted \\
\hline 8 & Restoration not assessed; child not present \\
\hline Codes: $0-2=$ Successful; 3-6= Failure; 7-8= Excluded \\
\hline
\end{tabular}




\section{Results}

The mean age of children at the baseline was 6.23 years. The number of children examined after 6 and 12 months was 57 (114 restorations) and 54 (106 restorations), respectively. The dropout rate was $5 \%$ in the first assessment and $10 \%$ in the second assessment. The total success rate of all ART restorations placed was $85.96 \%$ in the first assessment and $79.62 \%$ in the second assessment. The success rate of ART restorations placed in school environment was $84.2 \%$ in the first assessment and $77.77 \%$ in the second assessment (Table 2). The success rate of ART restorations placed in hospital dental setup in these two assessments was $87.7 \%$ and $81.48 \%$, respectively (Table 2 ). There was no statistically significant difference between the ART restorations placed in school environment and in hospital dental setup $(\mathrm{P}=0.641)$ and in the second assessment $(\mathrm{P}=0.573)$. Most successful restorations were assessed to be in good condition (code- 0 ), while the main reason of failure was that the restoration was missing (code-5) (Table 2). ried success rate for retention from $63 \%$ to $100 \%$ (16-23). ART procedure has been performed by few researchers in clinical dental setup on children (7). But, there are no studies to directly compare the efficacy of ART procedure performed in hospital dental setup and in school environment or field. Patient and operator positioning, illumination, operator comfort and accessibility for excavation of decay are the few factors that influence the efficacy of ART restoration. The objective of this study was to assess the longevity of class I single surface ART restorations and also to directly compare the efficacy of ART restorations in school and in hospital dental setup. For comparative purposes, the clinical criteria used to assess the quality of ART restorations in this study were similar to those used in previous ART studies $(24,25)$. The one year overall (54 children, 106 restorations) success rate of Class I ART restorations in this study $(79.62 \%)$ was close to that reported in an earlier study in Thailand (26), which was $79 \%$. This success rate was lower than that observed in other recent studies in China $(24,27)$ and Turkey $(28)$ which reported a success rate in excess of $90 \%$ up to $100 \%$.

Table 2. Survival Status of ART Restorations After 6 and 12 Months.

\begin{tabular}{|l|l|l|l|l|}
\hline \multirow{2}{*}{ ART Restoration status } & \multicolumn{2}{|l|}{$\begin{array}{l}\text { 6 months evaluation(N=57, ART } \\
\text { fillings=114) }\end{array}$} & $\begin{array}{l}\text { 12 months evaluation(N=54, ART } \\
\text { fillings=108) }\end{array}$ \\
\cline { 2 - 5 } & $\begin{array}{l}\text { In school } \\
\text { environment } \mathrm{N}\end{array}$ & $\begin{array}{l}\text { In hospital dental } \\
\text { setup } \\
\mathrm{N}(\%)\end{array}$ & $\begin{array}{l}\text { In school } \\
\text { environment } \\
\mathrm{N}(\%)\end{array}$ & $\begin{array}{l}\text { In hospital dental } \\
\text { setup } \\
\mathrm{N}(\%)\end{array}$ \\
\hline Success, in good condition & $41(71.9)$ & $44(77.19)$ & $34(62.96)$ & $37(68.51)$ \\
\hline $\begin{array}{l}\text { Success, slight marginal } \\
\text { defect }\end{array}$ & $3(5.26)$ & $3(5.26)$ & $4(7.04)$ & $4(7.04)$ \\
\hline Success, slight wear & $4(7.01)$ & $3(5.26)$ & $4(7.04)$ & $3(5.55)$ \\
\hline $\begin{array}{l}\text { Failed, gross marginal } \\
\text { defect }\end{array}$ & $2(3.5)$ & $1(1.75)$ & $2(3.70)$ & $2(3.70)$ \\
\hline Failed, gross wear & 0 & 0 & $2(3.70)$ & $1(1.85)$ \\
\hline $\begin{array}{l}\text { Failed, restoration partly or } \\
\text { completely missing }\end{array}$ & $7(12.28)$ & $6(10.52)$ & $8(14.81)$ & $7(12.96)$ \\
\hline $\begin{array}{l}\text { Failed, restoration replaced } \\
\text { by another filling }\end{array}$ & 0 & 0 & 0 & 0 \\
\hline Total & $57(100)$ & $57(100)$ & $54(100)$ & $54(100)$ \\
\hline & $\begin{array}{l}\text { No significant difference; } \mathrm{P}>0.05 \\
(\mathrm{P}=0.641)\end{array}$ & $\begin{array}{l}\text { No significant difference; } \mathrm{P}>0.05 \\
(\mathrm{P}=0.573)\end{array}$ \\
\hline
\end{tabular}

\section{Discussion}

GIC is always the material of choice in the ART technique. This is because of its chemical adherence to dental tissue, coefficient of thermal expansion similar to that of a tooth (9), biocompatibility properties (10), and caries protective effect through the release of fluoride $(10,11)$, which has antibacterial properties $(3,12)$ and potentiates remineralization that may prevent the development of secondary caries (13). Furthermore, GIC restorations may act as a rechargeable fluoride release system $(14,15)$.

The ART approach has been field-tested for a number of years in various countries on children's giving the va-
Explanation for the moderate success rate in this study may be due to the varying size of ART restorations performed. Lo et al. (25) and Holmgren et al. (29) noted that the survival rate of small Class I ART restorations was much higher than that of the large ones. In this study, no attempt was made to classify ART restorations according to size; the major concern was to find bilateral matched pairs of occlusal caries in primary molars. Bilateral matched pair of occlusal caries was selected to nullify the effect of individual dietary pattern or food habits which may influence the retention of ART restorations for a particular individual. Although for any reason, if the individual is practicing unilateral chewing 
habit, which may also influence the retention of ART restorations bilaterally, this factor was not considered in this study.

The success rates of ART restorations performed in hospital dental setup was slightly higher than that in school environment assessed at six months and 12 months, no statistically significant difference was observed, between the two ART approaches in both assessments. The main cause of ART restoration failure in this study was due to loss of the restoration. This agrees with previous studies concerning the survival of ART restorations in the primary dentition $(16,22,28,30)$, which may be due to the failure of the ART technique to establish a desirable design to accommodate the anatomical or morphological structural limitations in the primary teeth, the failure to control salivary contamination in children, and the fact that shallow ART restorations may be more susceptible to dislodgment in primary teeth. This reflects the need for ART material with improved physical properties, especially in stress-bearing areas.

The loss of restorations and replacements were the predominant failure characteristics for Class I ART restorations in permanent teeth in some studies $(20,25)$. Unacceptable defects at the margins and restorations were the main cause of failure in other studies $(19,21)$. Gross marginal defects and secondary caries were the major causes of ART restoration failures in a recent study (30).

\section{Conclusions}

Based on this study's results, the following conclusions can be made:

1. The 1-year success rate of occlusal Class I ART restorations in primary molars was moderately successful.

2. The ART technique's done in hospital dental setup was not proven to be better than restorations placed in school environment.

4. The main cause of ART restoration failure was loss of the restoration.

\section{References}

References with links to Crossref - DOI

1. Smales RJ, Yip HK. The atraumatic restorative treatment (ART) approach for primary teeth: review of literature. Pediatr Dent. 2000;22:294-8

2. Frencken JE, Pilot T, Songpaisan Y, Phantumvanit P. Atraumatic restorative treatment (ART): rationale, technique, and development. J Public Health Dent. 1996;56:135-40.

3. Carvalho TS, Ribeiro TR, Bönecker M, Pinheiro EC, Colares V. The atraumatic restorative treatment approach: an "atraumatic" alternative. Med Oral Patol Oral Cir Bucal. 2009;14:e668-73.

4. Schriks MC, van Amerongen WE. Atraumatic perspectives of ART: psychological and physiological aspects of treatment with and without rotary instruments. Community Dent Oral Epidemiol. 2003;31:15-20.

5. Mjör IA, Gordan VV. A review of atraumatic restorative treatment (ART). Int Dent J. 1999;49:127-31.

6. Honkala S, Honkala E. Atraumatic dental treatment among Finnish elderly persons. J Oral Rehabil. 2002;29:435-40.

7. Honkala E, Behbehani J, Ibricevic H, Kerosuo E, Al-Jame G.
The atraumatic restorative treatment (ART) approach to restoring primary teeth in a standard dental clinic. Int J Paediatr Dent. 2003;13:172-9.

8. Tyas MJ, Anusavice KJ, Frencken JE, Mount GJ. Minimal intervention dentistry--a review. FDI Commission Project 1-97. Int Dent J. 2000;50:1-12.

9. Croll TP, Nicholson JW. Glass ionomer cements in pediatric dentistry: review of the literature. Pediatr Dent. 2002;24:423-9.

10. Hume WR, Mount GJ. In vitro studies on the potential for pulpal cytotoxicity of glass-ionomer cements. J Dent Res. 1988;67:915-8.

11. Forsten L. Fluoride release and uptake by glass-ionomers and related materials and its clinical effect. Biomaterials. 1998;19:503-8.

12. Duque C, Negrini Tde C, Hebling J, Spolidorio DM. Inhibitory activity of glass-ionomer cements on cariogenic bacteria. Oper Dent. 2005;30:636-40.

13. Smales RJ, Gao W. In vitro caries inhibition at the enamel margins of glass ionomer restoratives developed for the ART approach. J Dent. 2000;28:249-56.

14. Donly KJ, Nelson JJ. Fluoride release of restorative materials exposed to a fluoridated dentifrice. ASDC J Dent Child. 1997;64:24950 .

15. Marinelli CB, Donly KJ, Wefel JS, Jakobsen JR, Denehy GE. An in vitro comparison of three fluoride regimens on enamel remineralization. Caries Res. 1997;31:418-22.

16. Taifour D, Frencken JE, Beiruti N, van 't Hof MA, Truin GJ. Effectiveness of glass-ionomer (ART) and amalgam restorations in the deciduous dentition: results after 3 years. Caries Res. 2002;36:43744.

17. Taifour D, Frencken JE, Beiruti N, van't Hof MA, Truin GJ, van Palenstein Helderman WH. Comparison between restorations in the permanent dentition produced by hand and rotary instrumentation--survival after 3 years. Community Dent Oral Epidemiol. 2003;31:122-8

18. Frencken JE, Taifour D, van 't Hof MA. Survival of ART and amalgam restorations in permanent teeth of children after 6.3 years. J Dent Res. 2006;85:622-6.

19. Frencken JE, van't Hof MA, Taifour D, Al-Zaher I. Effectiveness of ART and traditional amalgam approach in restoring single-surface cavities in posterior teeth of permanent dentitions in school children after 6.3 years. Community Dent Oral Epidemiol. 2007;35:207-14.

20. Phantumvanit P, Songpaisan Y, Pilot T, Frencken JE. Atraumatic restorative treatment (ART): a three-year community field trial in Thailand--survival of one-surface restorations in the permanent dentition. J Public Health Dent. 1996;56:141-5.

21. Frencken JE, Makoni F, Sithole WD, Hackenitz E. Three-year survival of one-surface ART restorations and glass-ionomer sealants in a school oral health programme in Zimbabwe. Caries Res. 1998;32:119-26.

22. Frencken JE, Makoni F, Sithole WD. ART restorations and glass ionomer sealants in Zimbabwe: survival after 3 years. Community Dent Oral Epidemiol. 1998;26:372-81.

23. Menezes JP, Rosenblatt A, Medeiros E. Clinical evaluation of atraumatic restorations in primary molars: a comparison between 2 glass ionomer cements. J Dent Child (Chic). 2006;73:91-7.

24. Lo EC, Holmgren CJ. Provision of Atraumatic Restorative Treatment (ART) restorations to Chinese pre-school children--a 30-month evaluation. Int J Paediatr Dent. 2001;11:3-10.

25. Lo EC, Holmgren CJ, Hu D, van Palenstein Helderman W. Sixyear follow up of atraumatic restorative treatment restorations placed in Chinese school children. Community Dent Oral Epidemiol. 2007;35:387-92.

26. Frencken JE, Songpaisan Y, Phantumvanit P, Pilot T. An atraumatic restorative treatment (ART) technique: evaluation after one year. Int Dent J. 1994;44:460-4.

27. Yip HK, Smales RJ, Yu C, Gao XJ, Deng DM. Comparison of atraumatic restorative treatment and conventional cavity preparations for glass-ionomer restorations in primary molars: one-year results. Quintessence Int. 2002;33:17-21. 
28. Ersin NK, Candan U, Aykut A, Onçağ O, Eronat C, Kose T. A clinical evaluation of resin-based composite and glass ionomer cement restorations placed in primary teeth using the ART approach: results at 24 months. J Am Dent Assoc. 2006;137:1529-36.

29. Holmgren CJ, Lo EC, Hu D, Wan H. ART restorations and sealants placed in Chinese school children--results after three years. Community Dent Oral Epidemiol. 2000;28:314-20.

30. Van Gemert-Schriks MC, van Amerongen WE, ten Cate JM, Aartman IH. Three-year survival of single- and two-surface ART restorations in a high-caries child population. Clin Oral Investig. 2007;11:337-43. 